\title{
Labour Taxation and Personnel Expenditure in the Romanian Public Sector
}

\author{
Maria-Andrada GEORGESCU* ${ }^{*}$ \\ Dana Mihaela MURGESCU ${ }^{* *}$
}

\section{National economic context around the economic crisis}

The global economic crisis which began in 2008 originated as a crisis in, and of, the financial sector. The banks expanded lending to people beyond what was sustainable. The crisis in the financial sector lead to a crisis in the rest of the economy, globally, as the banks stopped lending to people and companies, and so the level of spending and consumption by the private sector fell. The lack of credit and the fall in spending lead to companies cutting production and going bankrupt, both of which brought about increased unemployment and further reduction on consumption.

The debut of the economic-financial crisis in Romania was recorded at the beginning of the second semester of year 2008 .

Since in the fall of 2008 parliamentary elections had been scheduled, the members of the Executive and the Romanian dignitaries ensured population that the country will not be affected by this crisis. Moreover, prior to the parliamentary elections the President of Romania promulgated the law to increase the salaries of the teaching staff by 50\%, starting January $1^{\text {st }}, 2009$, law that is still in effect but was never applied.

At the beginning of year 2009, Romania officially admitted being in economic crisis, which became the subject of public debates.

\footnotetext{
Maria-Andrada Georgescu, Ph.D. - Lecturer, National School of Political Studies and Public Administration, Faculty of Public Administration, 6 Povernei St., Sector 1, cod 010643, Bucharest, Romania; <andradageor@yahoo.com>.

** Dana Mihaela Murgescu - Teaching Assistant, National School of Political Studies and Public Administration, Faculty of Public Administration, 6 Povernei St., Sector 1, cod 010643, Bucharest, Romania; <dana_akari@yahoo.com>.
} 
In the first trimester of the year, the social partners sent the Government anti-crisis proposals and subsequently, after consultations, the executive made public a program contested by the trade unions and employers' associations, which did not find inside their own measures.

In April, the government approved the letter of intent negotiated with the International Monetary Fund (IMF) for a loan in the amount of EUR 19.95 billion, out of which EUR 12.95 billion from the IMF, EUR 5 billion from the European Commission (EC) and EUR 1 billion each from the World Bank (WB) and the European Bank for Reconstruction and Development (EBRD). The government claimed that the fundamental objective of the loan was represented by the desire to preserve jobs, to relaunch and credit the economy, such as, indirectly, to ensure the payment of salaries and pensions in Romania.

Year 2009 ended with a drop of the GDP, compared to the previous year, of $7.1 \%$.

\section{Fig. 1: Governmental Consolidated General Budget - Romania}

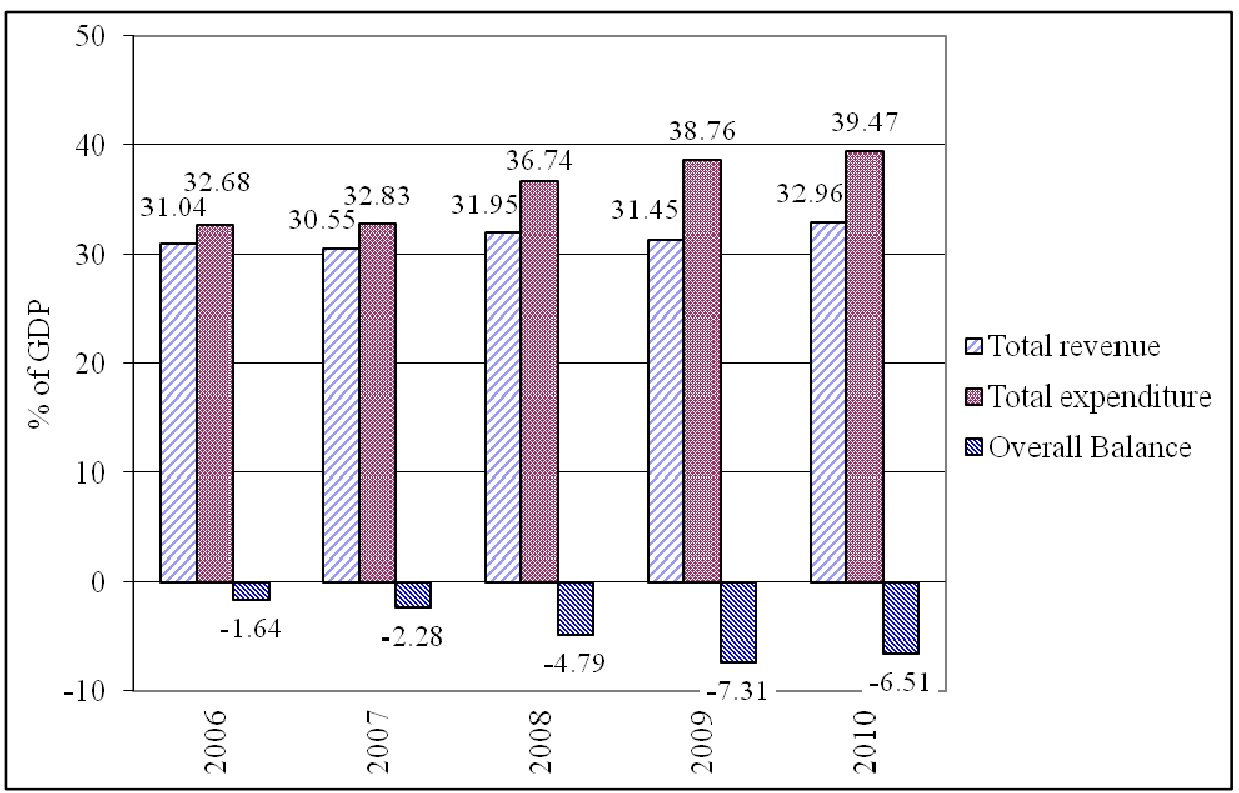

Source: Own calculation based on data of MFP Romania (2006-2011).

The recession had a general effect of reducing tax revenues, for all levels of government. As consumer spending falls, indirect taxes revenues fall; as unemployment increases, the volume of taxes on income decrease; 
as bankruptcies rise and profit fall, income from taxes on profits falls. The recession also increased the payment of unemployment and other benefits and services. Both the fall in taxes and the rise in benefits increased government deficits (see Fig. 1).

\section{Public expenditure policy in times of crisis}

The current financial policy, aiming to end the economic crisis in Romania, opted, apparently, as a saving solution, for the reduction of public expenditure. Moreover, the public expenditure of Romania's consolidated general budget was under the careful watch of the international institutions providing financial assistance to our country, in order to support it in surpassing the economic crisis and in ensuring a balanced economic development. Thus, the question is asked what public expenses represent in the entirety of the national economy, what effects the management errors in this field can have at the social-economic level. Public expenditure occurs as a result of the economic-social relations manifested between the state and the natural and legal persons, with the occasion of the redistribution and use of the state's financial resources, for the purpose of fulfilling its functions, on the basis of the Government's economic program (Georgescu, 2011).

In order to execute an analysis of the public expenditure comprised in the consolidated general budget of Romania, we will use the data regarding budgetary execution ${ }^{1}$.

\section{Tab. 1: Public Expenditure in Romania 2006 - 2010 Economic classification (in million lei)}

\begin{tabular}{|l|r|r|r|r|r|}
\cline { 2 - 6 } \multicolumn{1}{c|}{} & \multicolumn{1}{c|}{$\mathbf{2 0 0 6}$} & \multicolumn{1}{c|}{$\mathbf{2 0 0 7}$} & \multicolumn{1}{c|}{$\mathbf{2 0 0 8}$} & \multicolumn{1}{c|}{$\mathbf{2 0 0 9}$} & $\mathbf{2 0 1 0}$ \\
\hline $\begin{array}{l}\text { Total } \\
\text { expenditure }\end{array}$ & 112626.3 & 136556.5 & 189121.7 & 193679.3 & 201903.6 \\
\hline Social assistance & 30901.7 & 38326.7 & 53592.4 & 63957.6 & 68601.9 \\
\hline $\begin{array}{l}\text { Compensation } \\
\text { of employees }\end{array}$ & 21057.0 & 25588.9 & 43344.5 & 46837.6 & 42806.5 \\
\hline
\end{tabular}

1 The data regarding the budgetary execution are those published in the MPF Monthly Bulletin, available at www.mfinante.ro. They are computed according to national methodology. 


\begin{tabular}{|l|r|r|r|r|r|}
\cline { 2 - 6 } \multicolumn{1}{c|}{} & \multicolumn{1}{c|}{$\mathbf{2 0 0 6}$} & \multicolumn{1}{c|}{$\mathbf{2 0 0 7}$} & \multicolumn{1}{c|}{$\mathbf{2 0 0 8}$} & \multicolumn{1}{c|}{2009} & \multicolumn{1}{c|}{$\mathbf{2 0 1 0}$} \\
\hline $\begin{array}{l}\text { Goods and } \\
\text { services }\end{array}$ & 22744.8 & 25835.1 & 33225.5 & 28325.9 & 29801.2 \\
\hline Subsidies & 7429.4 & 6873.1 & 7835.6 & 7215.4 & 6734.6 \\
\hline Interests & 2489.7 & 2739.7 & 3893.3 & 6060.6 & 7247.0 \\
\hline $\begin{array}{l}\text { Capital } \\
\text { expenditures }\end{array}$ & 12717.0 & 14410.4 & 23203.4 & 21940.3 & 19368.9 \\
\hline $\begin{array}{l}\text { Other expenses } \\
\text { Other current } \\
\text { transfers }\end{array}$ & 14224.4 & 2110.0 & 5473.8 & 2182.7 & 4280.1 \\
\hline
\end{tabular}

Source: Own calculation based on data of MFP Romania (2006-2011).

Fig. 2: Structure of expenses in the Consolidated General Budget of Romania - \% of total expenditure

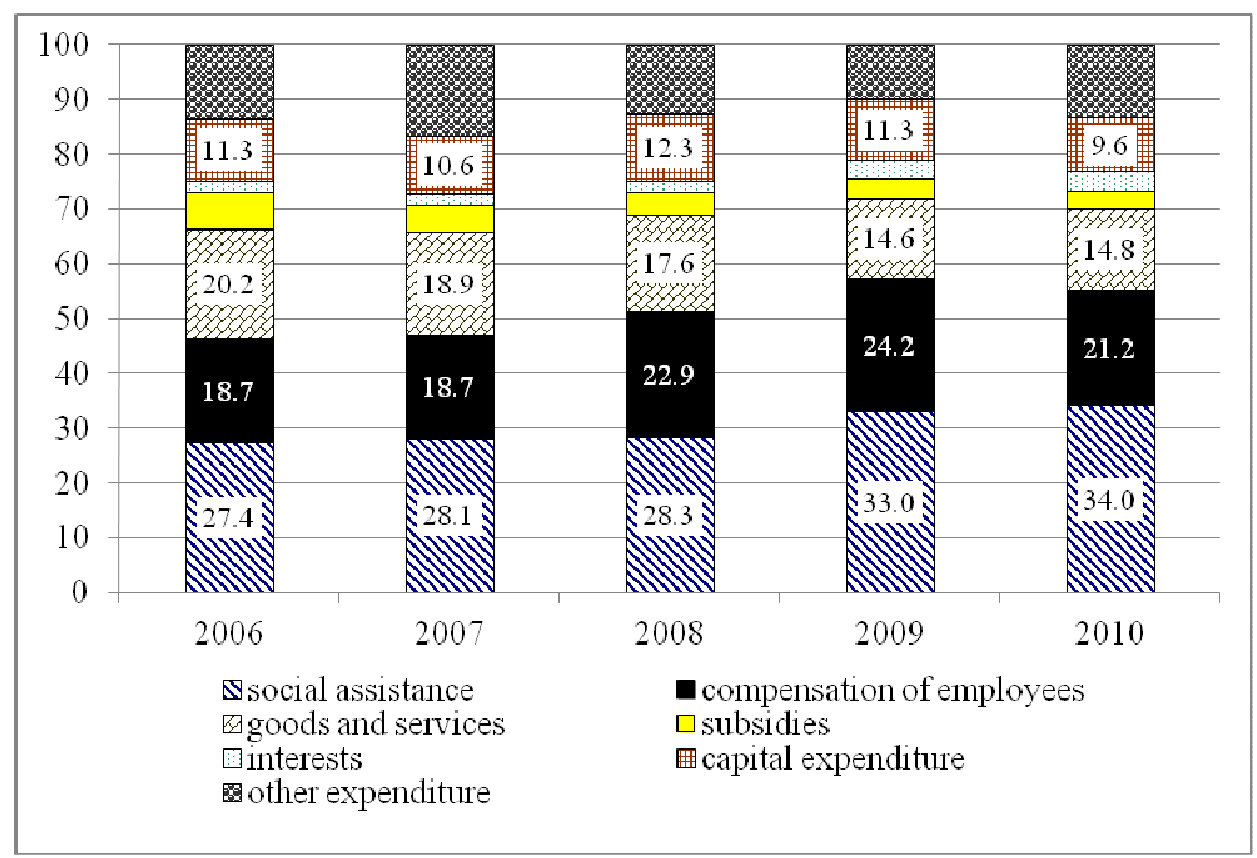

Source: Own calculation based on data of MFP Romania (2006-2011). 
Fig. 3: Public Expenditure in Romania 2006 - 2010 Economic classification, percent of GDP

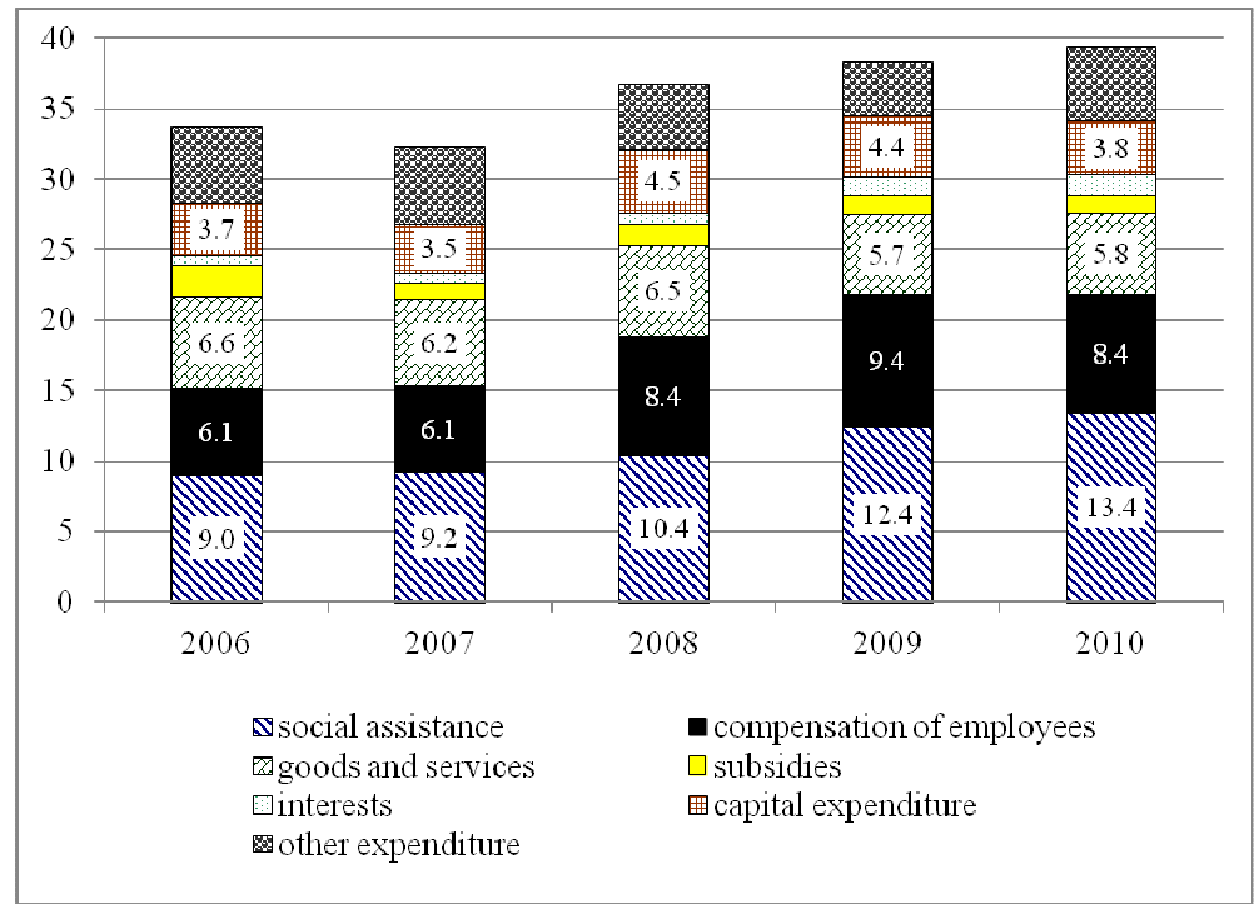

Source: Own calculation based on data of MFP Romania (2006-2011).

Examining the data in Tab. 1 and Fig. 3, we can see that the amount of the total public expenditure comprised in the consolidated general budget registered a permanent increase, of course, at different rates, both as absolute value, and as percentage of the GDP.

The expenses of the general budget increased in nominal terms in year 2010 with $4.6 \%$ compared to year 2009. However, in structure, the expenses had different evolutions. Thus:

- Expenses with interest for financing the deficit and for refinancing the public debt increased by $20 \%$ in 2010 . The volume of expenses with interest reached 7.3 billion lei, becoming an important risk factor for the control of the budgetary deficit;

- Expenses with social assistance increased with $7.3 \%$ in year 2010 compared to 2009, as a consequence of the increase of expenses with unemployment aid; 
- Also, the expenses with goods and services continued to rise. Compared to 2009, an increase of 5.2\% was recorded in 2010. At the level of the local administration, the increase of these expenses is due to the undertaking of the financing of the activity of Agricultural Chambers, as well as to the decentralization of health units, by their taking over by the local public authorities. At the same time, the increase of these expenses was determined by the increase of the expenditure of the National Single Fund of health social security, for the payment of outstanding amounts;

- In the last years, the Government was able to fall within the budgetary deficit targets, by sacrificing investments. The expenses meant for them, which also include capital expenses, as well as development programs financed from internal and external sources, although were in 2010 in the amount of 33.7 billion lei, respectively $6.6 \%$ of the GDP, they registered a decrease, compared to 2009 , with $11.7 \%$;

- The personnel expenditure decreased in 2010, compared to the previous year, with $8.6 \%$, being performed both lay-offs and reductions of salaries in the public sector.

With these data available, we reach the following conclusion: the entire adjustment of the budgetary deficit, which demonstrates the governmental "performance" in Romania, was achieved due to the $25 \%$ reduction of the public sector salaries.

In addition to this severe reduction, the Government also raised the VAT quota by 5 p.p., respectively from $19 \%$ to $24 \%$.

The increase of taxation operated by the VAT increase and by other less important measures faces the implacable decline of the economy, such as, although the Government collected more money from VAT $(+14.3 \%$ in year 2010 compared to 2009), the total fiscal collections stagnated. Practically, the decrease recorded in the collections afferent to profit tax $(-4.9 \%)$, income tax $(-3.2 \%)$ and social security contributions $(-4.5 \%)$ counterbalanced the higher VAT collection.

Moreover, the deficit of the general consolidated budget of 33.3 billion lei, respectively $6.5 \%$ of the GDP registered at the end of 2010 is below the limit of the deficit target, in the amount of 34.6 billion lei, set as objective of the budgetary policy for year 2010 and established in the additional letter to the Stand-by agreement concluded with the IMF. 
Was it really necessary to reduce the personnel expenditure in the public sector by $25 \%$ ? We ask this question considering the effects of this reduction on consumption and on the main macro-economic indicators. Namely, the reduction of public sector wages also determined the reduction of the budgetary incomes, both from VAT (due to lower consumption), and from the direct taxes of public sector employees' wages.

Elasticity of consumption depending on the income for families with at least 1 employee and where at least 1 employee works for the state, according to the NSB (National Syndical Block) estimates, and which can save money monthly, is of approximately $60 \%$. This elasticity is used for the realistic scenario regarding the impact of the decrease of public sector wages on consumption and GDP $(60 \%$ of the $25 \%$ reduction will reflect in the decrease of consumption). The realistic scenario is coherent with the situation of a family made up of one state employee and one private employee (hence, an average decrease of $15 \%$ in the family income). The optimistic scenario takes into consideration a lower elasticity (40\%), assuming that there are other resources for saving, and the pessimistic scenario takes into account a higher elasticity (80\%), assuming that other expenses are more rigid (utilities; bank installments). The pessimistic scenario is coherent with the situation of a family in which both spouse are state employees. The computation was performed at the level of a family, using the data from the Inquiry on Family Budgets executed by the NSI (National Statistics Institute). The weight in the consumption of families with at least 1 state employee is of approximately $30 \%$, and the weight of consumption in the GDP of approximately 60\%. Therefore, in the realistic scenario, we are dealing with a decrease of the familial consumption with $15 \%$, which leads to a decrease of $4.5 \%$ in the total annual consumption, which reflects in a contraction of the annual GDP with $2.7 \%$, respectively $1.58 \%$ for the period June-December 2010. Thus, the effect of the decrease in salaries on the aggregated demand will contribute to the reduction of GDP with $1.35 \%$ from July until the end of year 2010, in the realistic scenario.

The reduction of the public sector wages will also have repercussions on the budgetary income. Although it is difficult to model the indirect effect (impact of the decreased consumption on the turnover, profit, number of employees and, implicitly, the profit tax and the tax on the work force paid by the private companies), it cannot be considered negligible. 
In exchange, with approximation, we can compute the direct effect of the salary drop by $25 \%$ on budgetary incomes, in view of the weight of $38 \%$ of the state employees' wages in the total wages in the economy.

Next, we take into account the following scenario: the Government decides to increase the VAT quota by 5 p.p., but does not reduce the public sector wages with $25 \%$. We computed the impact of this hypothesis on the consolidated general budget. In the hypothesis of maintaining the public employees' wages in 2010Q3 (third trimester) and 2010Q4 (fourth trimester) at the level registered in 2009Q3 and 2009Q4, the personnel expenditure would have increased with $0.6 \%$ of the GDP. At the same time, the incomes collected from the tax on wages and the social security contributions increase with $0.3 \%$ of the GDP. Ceteris paribus, the budgetary deficit at the end of year 2010 would have reached $6.75 \%$ of the GDR, still below the level agreed with the IMF $(6.8 \%$ of the GDP). Still, let us not forget that we did not take into account the increase of VAT incomes following this hypothesis, element which, of course, leads to the improvement in the deficit level.

Still, we agree that the reform of the total salary fund must not be eliminated, applying overall reductions with different percentages. As this measure was applied, it was equivalent with a regressive tax, the reduction of wages in an undifferentiated manner having perverse effects and not promoting fiscal sustainability. These reductions affect the quality of public services, which reduce the quantity and availability of public services, which, in the end, can have as result the continuous erosion of the population's trust in the government. Such (mass) reductions have only a limited and short-term effect. Usually, in such a situation, the first people leaving the public sector are those with superior training, which leads to a reduction of labour productivity in the budgetary sector. When the public sector will hire again, it will have to allot additional amounts of the professional training of the newcomers.

How was this decision reached? Is Romania a particular case?

\section{European examples of fiscal crisis management}

A number of EU countries have taken policy decisions to cut the pay of government and/or public sector employees between 2008-2010. It is worth mentioning the fact that half of these countries have reached IMF deals. 
Greece. In February 2010, the government of Greece adopted a package of cuts in public spending which included a $7 \%$ cut in earnings for all public sector jobs, as well as the cancellation of all agreed pay rises. The pay of public employees was further reduced following the agreement in March 2010 by the EC, the IMF, and the European Central Bank on a support package for Greece which included a 'Memorandum of understanding' on economic and fiscal policies. This led to a new law in May 2010, which included an $8 \%$ cut in earnings of all government employees and a 3\% cut in earnings of all workers employed by stateowned companies. Public sector pay is frozen until 2014 (Lampousaki, 2010, Kapsalis, 2010).

Hungary received a support loan from the IMF in October 2008. Part of the agreement was originally that public sector workers would lose their bonus, worth $8 \%$ of their pay, and face a pay freeze; the cut in earnings was later restored. However, in June 2010 a newly elected government announced a new package of measures designed to reduce the deficit to the level of $3.8 \%$ required by the EU/IMF, which included a 15\% cut in the salaries of all 700000 public sector employees (Bretton Woods Project, 2008).

Ireland. The government confirmed unilateral pay cuts in the budget of December 2009, which specified that from 1st January 2010 basic salaries of public employees would be reduced as follows: $5 \%$ on the first $€ 30000$ of salary; $7.5 \%$ on the next $€ 40000$ of salary; $10 \%$ on the next $€ 50000$ of salary. This produces overall reduction in salaries ranging from $5 \%$ to just under $8 \%$ in the case of salaries up to $€ 125000$ (Callan Nolan - Walsh, 2010).

Latvia faced acute problems arising from the financial crisis in 2008, which led to it securing an IMF stand-by arrangement worth more than $\$ 2.3$ billion at the end of 2008 . Public sector pay was cut by a succession of measures in 2008 and 2009: in mid-2008 additional payments and bonuses were cut; conditionalities for the IMF deal included a 15 per cent reduction in local government employees' wages, and a $30 \%$ cut in the wage bill in 2009; in July 2009 salaries of state sector workers were cut by between $15 \%$ and 20\%; from September 2009 teachers pay was cut by 28\% (Bretton Woods Project, 2009; Curkina, 2009). Lithuania. In June 2009 the Lithuanian government announced unilaterally that it was planning to cut the basic salaries of public sector employees by $10 \%$, with effect from August. The trade union confederation rejected the decision and organized 
action, including a hunger strike: the government then entered discussions with the unions, and agreed to suspend the unilateral decision. An agreement was signed in October 2009 between the government, private employers and a number of trade union organizations. It includes an obligation not to reduce basic salaries for civil servants, but also an overall austerity agreement involving general reductions in wages and social benefits. The prime minister claims that the austerity measures have been successful because they are based on 'social consensus': However, some independent trade unions and civil society groups refused to sign the 2009 agreement because of the plans to cut pensions, and criticize the process for lack of transparency and for agreeing that the burden of the crisis should fall on ordinary people (Blaziene, 2009).

Portugal. In early 2010, as a way of reducing the budget deficit, the government proposed a general freeze on wages, cuts in public sector pensions, 5\% pay cuts for senior civil servants and politicians only, and unilaterally decided to cut unemployment benefit and the minimum wage. This was strongly opposed by the unions and others, including a strike of 300000 workers in March, and one of the largest demonstrations ever recorded in Portugal, in May 2010. The private employers also opposed an increase in the national minimum wage, as agreed in the 2006 tripartite agreement: the government approved the increase, but provided a subsidy for employers (Lima, 2010a, 2010b).

Spain. In response to international markets' forcing up the cost of borrowing by Spain, the government introduced a number of measures in 2010 to try to reduce the budget deficit. In May 2010 the government announced a cut in public sector pay of $5 \%$ on average, a freeze on civil service pay in 2011, a freeze on pensions, and reductions in some benefits (Miguel, 2010).

From the data above, it can be seen that not in Romania was decided reductions of the public sector wages, but the percentage applied was, by far, the greatest.

Let's look at the evidence concerning comparative movements in public and private sector wages since the start of the crisis. Table 4 sets out data for the European countries on the changes in wages and salaries costs for the public and private sector. The data is presented using Eurostat's classification. The information must be used carefully because they refer to the statistics of the business economy activities (aggregated 
according to the homogenous activity), according to NACE Rev. 2, and the public sector includes public administration, education, healthcare and social assistance (includes the private sector for education, health and social assistance, excludes the armed forces and assimilated personnel). These statistics do not take into account the financing form, their goal being to supply information on economic activities, according to NACE 2 . The data is incomplete for a number of countries, with data covering the whole of the public/private sector, as defined above, for both 2008Q1 and 2010Q1. Given all this caution, it is still possible to identify some patterns in the relative movements in private and public sector earnings in 2-year period since the recession (between the first quarter of 2008 and the first quarter of 2010).

\section{Tab. 2: Change in wages and salaries, Europe, 2008Q1 - 2010Q1}

\begin{tabular}{|c|c|c|c|c|c|c|c|c|c|}
\hline & \multirow[b]{2}{*}{ 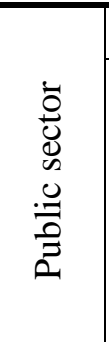 } & \multicolumn{3}{|c|}{ Of which } & \multirow[b]{2}{*}{ 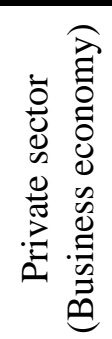 } & \multicolumn{4}{|c|}{ Of which } \\
\hline & & 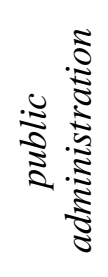 & 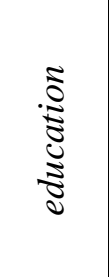 & 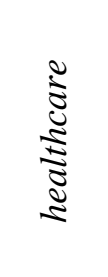 & & 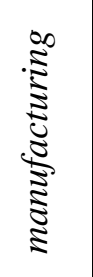 & 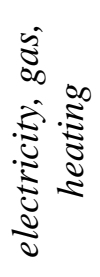 & 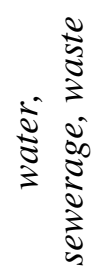 & 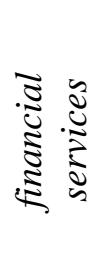 \\
\hline Bulgaria & 30.6 & 26.3 & 30.5 & 35.1 & 31.8 & 27.8 & 30.5 & 23.5 & 24.9 \\
\hline $\begin{array}{l}\text { Czech } \\
\text { Republic }\end{array}$ & 11.3 & 7.5 & 10.3 & 19.1 & 4.2 & 3.4 & 14.6 & 8.8 & 2.8 \\
\hline Germany & 4.9 & 6.4 & 5.4 & 3.3 & 3.4 & 3.7 & 3.2 & 3.5 & 1.8 \\
\hline Estonia & -0.5 & -2.7 & 3.5 & -2.2 & -3.7 & 0.6 & 16.6 & 4.5 & -7.5 \\
\hline Greece & 1.5 & -2.8 & 11.5 & -6.7 & 11.3 & 8.4 & 16.0 & 2.3 & 5.7 \\
\hline Spain & 5.4 & 4.8 & 6.9 & 5.5 & 6.9 & 7.4 & 6.4 & 3.0 & 3.1 \\
\hline Latvia & -18.8 & -26.5 & -18.1 & -13.0 & -0.4 & 2.0 & -2.7 & -2.1 & -5.6 \\
\hline Lithuania & -3.6 & -13.2 & 6.3 & -3.3 & -9.5 & -3.5 & 1.7 & -2.6 & -3.8 \\
\hline Hungary & -4.8 & -7.3 & -0.3 & -6.6 & 8.8 & 10.5 & 18.3 & 12.3 & 2.6 \\
\hline Poland & 14.7 & 15.0 & 15.5 & 15.0 & 8.5 & 8.9 & 14.4 & 12.6 & 6.2 \\
\hline Portugal & -3.1 & -1.0 & -8.0 & -0.2 & 3.7 & 3.5 & 16.5 & 4.6 & 1.2 \\
\hline Romania & 14.9 & 0.3 & 14.7 & 30.5 & 26.2 & 27.5 & 31.5 & 28.2 & 22.2 \\
\hline Slovenia & 13.8 & 7.6 & 9.7 & 27.8 & 12.0 & 16.4 & 16.6 & 14.7 & 8.1 \\
\hline Slovakia & 10.1 & 10.7 & 9.9 & 10.0 & 7.0 & 8.2 & 6.0 & 8.1 & 7.5 \\
\hline
\end{tabular}

Source: Own calculation based on Eurostat (2011) - Labour cost index, nominal value Quarterly data (Nace R2), Seasonally adjusted and adjusted data by working days. Index: $2008=100$. Extracted $7^{\text {th }}$ April, 2011 08:30:13. 
In 8 countries, public sector earnings increased more rapidly - or decreased less - than the earnings in the private sector. We include here the case of Lithuania, where public sector earnings fell by 3.6\%, less than the $9.5 \%$ fall in private sector earning, and Estonia, where public sector earnings fell by $0.5 \%$, less than the $3.7 \%$ fall in private sector earning. Only in Bulgaria public sector earnings rose more slowly than private sector earnings, but closet o the rate of private sector. In 5 countries (Greece, Spain, Hungary, Portugal, and Romania) public sector earnings have fallen relative to private sector.

Within the private sector, earnings in financial services performed relatively badly - on average there was a fall even in nominal terms, and in all countries, earnings in financial services did much worse than in the general movements in the private sector. In half of the countries, public sector pay performed significantly better than the financial services sector alone; earnings in the electricity and gas sectors also did consistently better than earnings in financial services.

However, if we analyze the data reflecting the modifications occurred in year 2010, we will notice that in all countries, except Lithuania, public sector earnings have fallen relative to private sector. The highest discrepancy is registered in Romania, where public sector earnings dropped by $21.5 \%$, while the private sector earnings increased by $2.7 \%$.

\section{Tab. 3: Change in wages and salaries, Europe, 2010Q1 - 2010Q4}

\begin{tabular}{|c|c|c|c|c|c|c|c|c|c|}
\hline & \multirow[b]{2}{*}{ 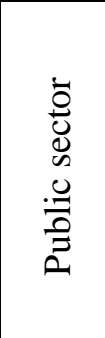 } & \multicolumn{3}{|c|}{ Of which } & \multirow[b]{2}{*}{ 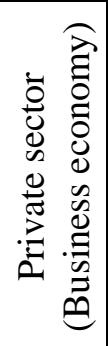 } & \multicolumn{4}{|c|}{ Of which } \\
\hline & & 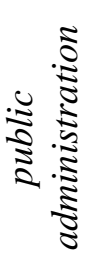 & 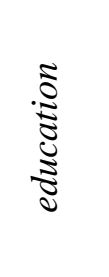 & 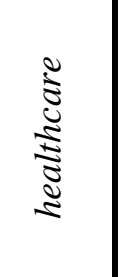 & & 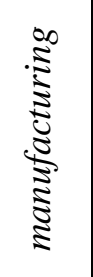 & 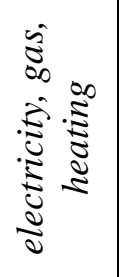 & 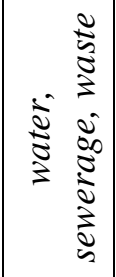 & 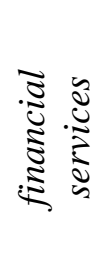 \\
\hline Bulgaria & 1.4 & -9.2 & 6.4 & 7.2 & 6.3 & 5.5 & 19.1 & 8.2 & 10.0 \\
\hline $\begin{array}{l}\text { Czech } \\
\text { Republic }\end{array}$ & 1.7 & 2.4 & 0.4 & 1.7 & 9.4 & 12.8 & 5.0 & 3.8 & 11.5 \\
\hline Germany & -0.7 & -2.2 & -1.6 & 0.4 & 1.0 & 1.0 & 2.8 & 1.6 & 1.5 \\
\hline Estonia & -3.5 & -4.8 & -7.7 & 2.7 & 3.0 & 2.0 & 0.7 & -2.8 & 7.3 \\
\hline Greece & -10.3 & 5.7 & -28.0 & -16.2 & -7.3 & -3.5 & -28.2 & -14.8 & -4.6 \\
\hline Spain & -2.8 & -3.5 & -3.0 & -2.9 & 0.8 & 1.0 & -0.4 & 2.5 & 1.7 \\
\hline
\end{tabular}




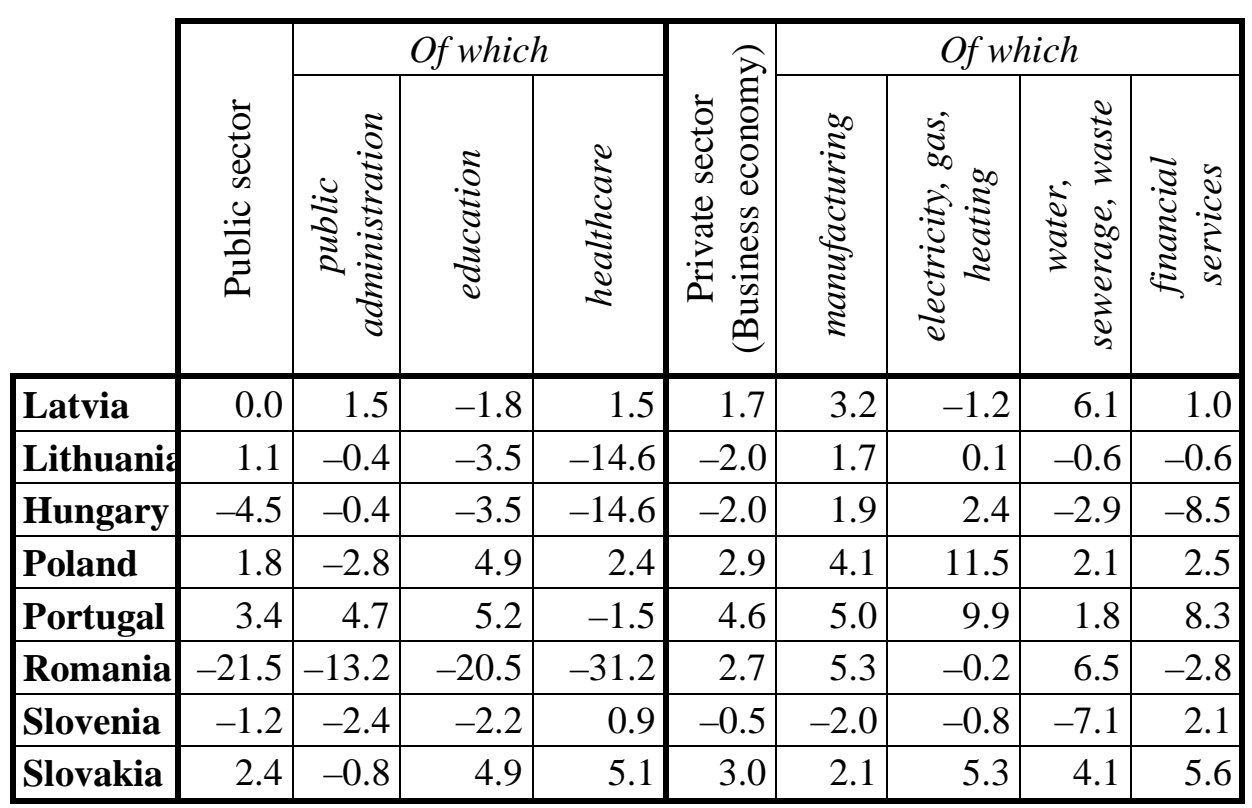

Source: Own calculation based on Eurostat (2011) - Labour cost index, nominal value Quarterly data (Nace R2), Seasonally adjusted and adjusted data by working days. Index: $2008=100$. Extracted $7^{\text {th }}$ April, 2011 08:30:13.

Most of the countries involved in process of reducing public sector wages have been the subject of external economic pressures, including pressure from the European Commission to keep deficits below the level of 3\% specified in the Maastricht Treaty and policies required by the IMF as condition for loans supporting national currencies.

Is there an economic justification for the cutting of the public sector wages? A document published in June 2010 by the ECB (see HolmHadulla, 2010), the evidence seems to suggest that there is no scientifically solid argumentation that would link the public sector pay with the economic recession. Nor is there evidence to support the idea that public sector wages reflect on the business cycle.

Moreover, at the level of the EU countries, there is no clear relation between the public and private wages. While in countries such as France or Finland, where the number of public employees is high, the salaries of the private and public sectors are almost identical. Still, there are countries where the average wage of a state employee exceeds by nearly $50 \%$ the average salary in the private sector. 
However, we must remember that public sector pay determination is much less likely to affect private sector wage settlements where trade unions have negotiation powers, which coincides with a weaker influence of the public wages.

In the previous part of the paper we attempted to demonstrate that it was not the public sector wages that determined the crisis, but governments proceeded to their reduction in order to achieve economic growth. As indicated, the reduction of public sector wages in Romania did not bring about merely the reduction of public expenditure, but also the diminishing of the taxes levied on (employed) labour income, which are usually withheld at source (i.e. personal income tax levied on wages and salaries income plus social security contributions).

In addition to the reduction of salary expenses in the public sector, Romania proceeded to a dramatic, sudden, violent reduction of the number of state employees without distinguishing criteria and, especially, without a preparation for the absorption of the work force laid off.

\section{Tab. 4: Number of employees in the public sector (thousands of persons, year end)}

\begin{tabular}{|l|l|r|r|r|r|r|r|}
\cline { 3 - 8 } \multicolumn{2}{l|}{} & $\mathbf{2 0 0 5}$ & $\mathbf{2 0 0 6}$ & $\mathbf{2 0 0 7}$ & $\mathbf{2 0 0 8}$ & $\mathbf{2 0 0 9}$ & $\begin{array}{l}\text { May } \\
\mathbf{2 0 1 0}\end{array}$ \\
\hline $\mathbf{1}$ & $\begin{array}{l}\text { Institutions fully financed } \\
\text { from the state budget }\end{array}$ & 287 & 314 & 336 & 339 & 348 & 345 \\
\hline $\begin{array}{l}\mathbf{2}= \\
\mathbf{3 + 4}\end{array}$ & $\begin{array}{l}\text { Institutions fully financed } \\
\text { from the local budgets, } \\
\text { out of which }\end{array}$ & 557 & 595 & 617 & 644 & 633 & 620 \\
\hline $\mathbf{3}$ & $\begin{array}{l}\text { - apparatus of local } \\
\text { councils and other local } \\
\text { institutions }\end{array}$ & 221 & 259 & 280 & 311 & 307 & 299 \\
\hline $\mathbf{4}$ & $\begin{array}{l}\text { - personnel instate pre- } \\
\text { university education }\end{array}$ & 336 & 336 & 338 & 333 & 325 & 321 \\
\hline $\mathbf{5}$ & $\begin{array}{l}\text { Other institutions } \\
\text { (CNPAS, CNASS, } \\
\text { ANOFM) }\end{array}$ & 13 & 11 & 12 & 11 & 11 & 11 \\
\hline
\end{tabular}




\begin{tabular}{|c|c|c|c|c|c|c|c|}
\hline & \multirow[b]{2}{*}{2005} & \multirow[b]{2}{*}{2006} & \multirow[b]{2}{*}{2007} & \multirow[b]{2}{*}{2008} & \multirow[b]{2}{*}{2009} & \multirow[b]{2}{*}{$\begin{array}{l}\text { May } \\
2010 \\
\end{array}$} \\
\hline & & & & & & & \\
\hline $\begin{array}{l}6= \\
1+2+5\end{array}$ & $\begin{array}{l}\text { Total positions in public } \\
\text { institutions and } \\
\text { authorities, excluding } \\
\text { institutions subsidized } \\
\text { from the state budget and } \\
\text { local budgets and the } \\
\text { institutions financed from } \\
\text { own incomes }\end{array}$ & 856 & 921 & 965 & 994 & 991 & 975 \\
\hline 7 & $\begin{array}{l}\text { Self-financed institutions } \\
\text { and institutions subsidized } \\
\text { from the state budget and } \\
\text { local budgets }\end{array}$ & 377 & 361 & 395 & 405 & 389 & 382 \\
\hline $\begin{array}{l}8= \\
6+7\end{array}$ & $\begin{array}{l}\text { Total positions in public } \\
\text { institutions and authorities }\end{array}$ & 1233 & 1281 & 1360 & 1399 & 1380 & 1358 \\
\hline
\end{tabular}

Source: Fiscal Council (2010)

In the almost total absence of measures for stimulating the real economy, compensatory for the massive personnel lay-offs, the perspective of increasing budgetary incomes and, respectively, salary incomes of the state employees appears as little probable in the immediately following period.

That is why we shall study the impact of labour taxation on the labour market.

Supporting labour demand and monitoring incentives to work calls for the assessment of both tax and benefit systems. The tax burden on labour as measured by the tax wedge is on average very high in Europe, although substantial differences exist across Member States. This heavy tax burden has been considered by some analysts as one of the main factors behind the unsatisfactory European employment performance in recent years.

The tax barrier to employment is usually measured by the tax wedge, the proportional difference between the cost of workers to their employer and the amount of net earnings that the worker receives (take-home pay). The tax wedge is composed of several elements. First, employers have to pay employers' social security contributions. Second, employees have to pay social security contributions on their wage income. Finally, the labour income is subject to the personal income tax. The tax wedge is calculated 
for different household types and different income levels relative to the gross wage earnings of an average worker. The effect of the tax wedge on labour demand and labour supply (and eventually on employment) depends on whether and to what extend the tax burden increases the total labour cost for the employer or is transferred on to the worker, translating into a lower net wage. When increasing the total labour cost, taxes on labour (notably in the form of employer's social security contributions) tend to reduce labour demand. On the labour supply side, taxes levied on wages (both direct taxation on labour income and employee's social security contributions) reduce the net income and drive a wedge between the marginal product of labour and the marginal value of leisure. They thus tend to discourage the availability to work, especially at the lower end of the wage scale due to higher labour supply elasticity of low income workers.

Tab. 5: The composition of tax wedge in 2009, single average income worker

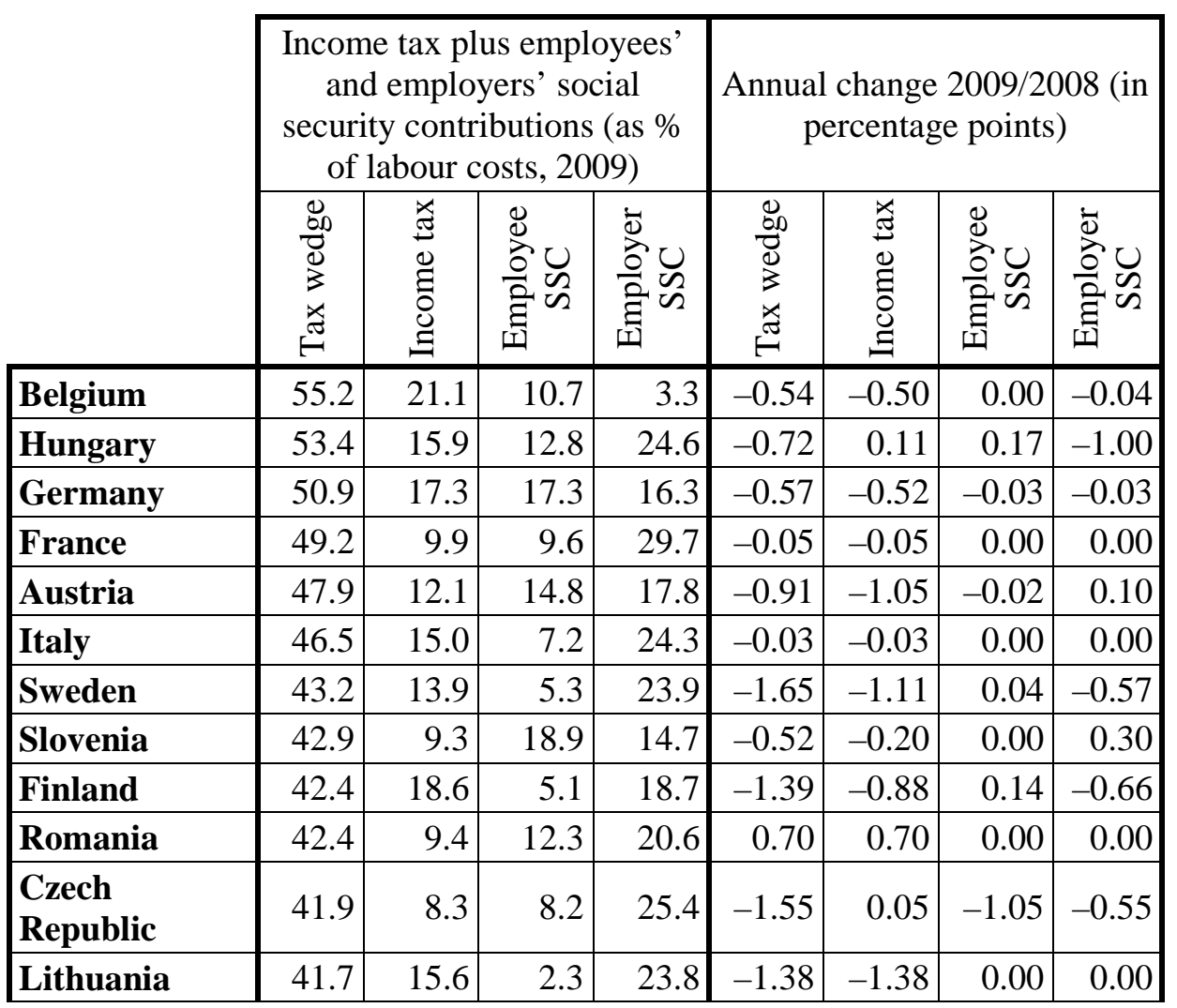




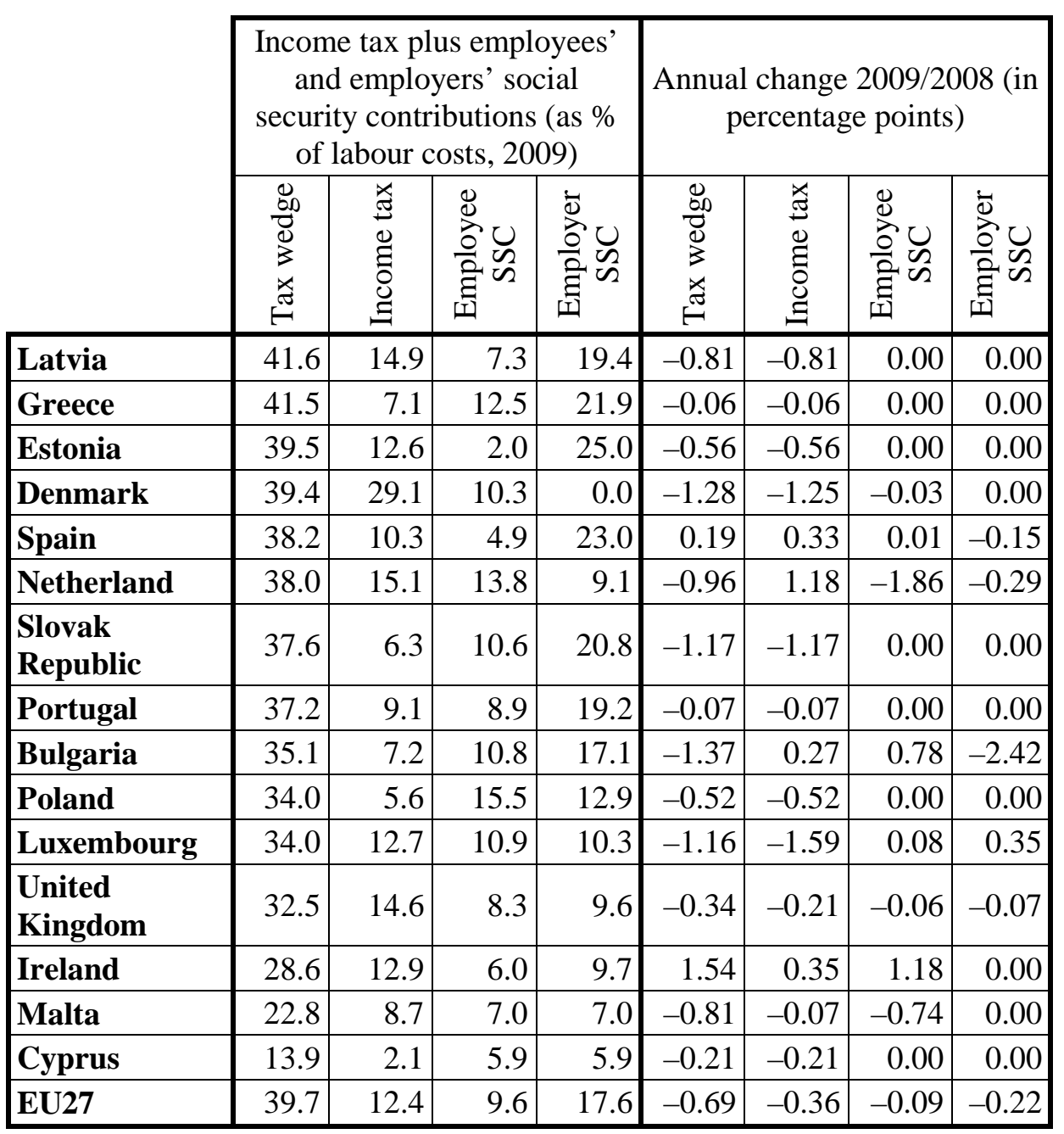

Source: European Commission (2010).

In the EU, employers' social security contributions constitute the largest part of the tax wedge for the single average income worker in about two thirds of the EU countries (17.6\% of labour costs for the unweighted EU average in 2009). The second largest component of the tax wedge is income tax (12.4\%), followed by employee's social security contributions (9.6\%). Compared to the European average, Romania's situation presents as follows: indeed, the largest part of the tax wedge is constituted by the employers' social security contributions (with 3 p.p. higher than the EU average), the second largest component of the tax wedge is employee s social security contributions (with 22.7 p.p. higher 
than the EU average), and lastly, the income tax (cu 2.8 p.p. lower than the EU average).

Moreover, a recent study performed by KPMG (2010) places Romania on $4^{\text {th }}$ position in what concerns the effective employer and employees social security rates on USD 100000 of gross income and on $3^{\text {rd }}$ position taking into account USD 300000 of gross income (after France and Belgium). The study also reveals the fact that these effective rates are the same, regardless of the level of gross income, i.e. effective employer social security rate is $27.2 \%$ and effective employee social security rate is $16.5 \%$.

Tab. 6: Social security contributions in NMS in 2010 (\%)

\begin{tabular}{|c|l|r|r|r|r|r|r|r|r|r|r|}
\hline \multicolumn{2}{|c|}{$\begin{array}{c}\text { Social } \\
\text { contributions }\end{array}$} & SK & HU & CZ & RO & PL & LT & SL & LV & EE & BG \\
\hline $\begin{array}{c}\text { Old- } \\
\text { age }\end{array}$ & Employer & 14.0 & 24.0 & 21.5 & 20.8 & 9.8 & 23.3 & 8.9 & - & - & 8.9 \\
pens. & Employee & 4.0 & 9.5 & 6.5 & 10.5 & 9.8 & 3.0 & 15.5 & - & - & 7.1 \\
\hline Un- & Eotal & $\mathbf{1 8 . 0}$ & $\mathbf{3 3 . 5}$ & $\mathbf{2 8 . 0}$ & $\mathbf{3 1 . 3}$ & $\mathbf{1 9 . 5}$ & $\mathbf{2 6 . 3}$ & $\mathbf{2 4 . 4}$ & - & - & $\mathbf{1 6 . 0}$ \\
employer & 1.0 & - & 1.2 & 0.5 & - & 1.1 & 0.1 & - & - & 0.4 \\
ins. & Employee & 1.0 & - & - & 0.5 & - & - & 0.1 & - & - & 0.6 \\
\hline \multirow{2}{*}{ H. } & Total & $\mathbf{2 . 0}$ & - & $\mathbf{1 . 2}$ & $\mathbf{1 . 0}$ & - & $\mathbf{1 . 1}$ & $\mathbf{0 . 2}$ & - & - & $\mathbf{1 . 0}$ \\
ins. & Employer & 10.0 & 2.0 & 9.0 & 5.2 & - & 3.0 & 7.1 & - & - & - \\
& Employee & 4.0 & 6.0 & 4.5 & 5.5 & 9.0 & 6.0 & 6.4 & - & - & 8.0 \\
& Total & $\mathbf{1 4 . 0}$ & $\mathbf{8 . 0}$ & $\mathbf{1 3 . 5}$ & $\mathbf{1 0 . 7}$ & $\mathbf{9 . 0}$ & $\mathbf{9 . 0}$ & $\mathbf{1 3 . 5}$ & - & - & $\mathbf{8 . 0}$ \\
\hline \multirow{3}{*}{ Other } & Employer & 10.2 & 4.0 & 2.6 & 1.4 & 4.9 & 3.7 & 0.1 & - & - & 1.8 \\
& Employee & 4.4 & 3.0 & - & - & 4.0 & - & 0.1 & - & - & 2.1 \\
& Total & $\mathbf{1 4 . 6}$ & $\mathbf{7 . 0}$ & $\mathbf{2 . 6}$ & $\mathbf{1 . 4}$ & $\mathbf{8 . 9}$ & $\mathbf{3 . 7}$ & $\mathbf{0 . 2}$ & - & - & $\mathbf{3 . 9}$ \\
\hline \multirow{2}{*}{ Total } & Employer & 35.2 & 30.0 & 34.3 & 27.9 & 14.7 & 31.1 & 16.1 & 24.1 & 33.0 & 11.1 \\
& Employee & 13.4 & 18.5 & 11.0 & 16.5 & 22.7 & 9.0 & 22.1 & 9.0 & - & 17.8 \\
& Total & $\mathbf{4 8 . 6}$ & $\mathbf{4 8 . 5}$ & $\mathbf{4 5 . 3}$ & $\mathbf{4 4 . 4}$ & $\mathbf{4 1 . 2}$ & $\mathbf{4 0 . 1}$ & $\mathbf{3 8 . 2}$ & $\mathbf{3 3 . 1}$ & $\mathbf{3 3 . 0}$ & $\mathbf{3 0 . 5}$ \\
\hline
\end{tabular}

Row legends: Old-age pens. $=$ Old-age pensions, Unempl. ins. = Unemployment insurance, $\mathrm{H}$. ins. = Health insurance.

Column legends: $\mathrm{SK}=$ Slovak Republic, $\mathrm{HU}=$ Hungary, $\mathrm{CZ}=$ Czech Republic, $\mathrm{RO}=$ Romania, $\mathrm{PL}=$ Poland, $\mathrm{LT}=$ Lithuania, $\mathrm{SL}=$ Slovenia, $\mathrm{LV}=$ Latvia,

$\mathrm{EE}=$ Estonia, $\mathrm{BG}=$ Bulgaria .

Source: European Commission (2010) 
Having figures in mind, we strongly suggest the reduction of social security contributions for employers. A reduction by 3 p.p. of the SSC paid by the employers and employees (from a total percentage of $44 \%$ to $41 \%$ of the contributions afferent to each gross salary) could lead to the creation of 100000 new work places. On the other hand, the state collects from social contributions approximately 22.9 billion lei during a period of 6 months, at a contribution amount of $44 \%$ of the employee's gross incomes. If the contribution percentage is reduced to $41 \%$, the amount collected by the state decreases to 21.3 billion lei, which means that the collections to the budget are reduced by 1.6 billion lei (approximately 380 million Euros), money that could remain at the disposal of companies. This measure would mean a reduction of the cost with wages of the employer, but the impact depends on the company size. At an average wage of 2000 lei in a company with 1000 employees, the reduction would mean savings of 60000 lei per month (approximately 14300 Euros), but in a company with two employees, at the same average wage, the reduction would be insignificant, of 80 de lei (19 Euros). Still, for a company with 100 employees who receive the average wage in the economy, with an average gross expense of the employer of 2500 lei/employee, the savings derived from the reduction of the social security contributions paid by employer with 3 p.p. would reach 90000 lei, meaning 21500 Euros per year, money with which an employer would be able to support the salary expenses of at least 3 new employees.

A big problem that Romania has is represented by the low number of employees working legally. Actually, Romania has reached the minimum number of employees in the last 50 years - only 4.095 million persons with legal employment contracts at the end of January $2011^{2}$.

The reduction of social contributions is a good measure for stimulating economic growth because, at the current level, the social security contributions remain a fiscal burden on the employer. A reduction by 3 p.p. of the social security contributions rate paid by the

2 According to the NSI, in 1990 in Romania there was an average number of employees in the economy of 8156 thousand persons. The evolution of this number was constantly descending until year 2004, when a number of 4469 thousand persons was recorded. In the interval 2005-2008, the trend inversed, such as in 2008 the average number of employees reached 5046 thousand. Starting with 2009, the number of employees continued to decrease, on the grounds of the economic crisis and of the massive lay-offs of the budgetary emoployees, such as in 2010 a number of 4368 thousand persons was recorded. 
employer would mean good news for the private sector, in the conditions in which this sector has experienced more than 700000 lay-offs since 2009 (year during which it was decided to increase the contributions for pensions paid by the employer, from $18.5 \%^{3}$ to $20.8 \%$, the current level).

Considering the high level of the social contributions rate, we believe that their reduction is necessary in for the increase Romania's competitiveness and attractiveness before investors.

\section{Conclusions}

Public administration, or, better said, the professional quality and its moral responsibility represent the key institutional factors of the political efficiency of governance in this difficult period, under the economic, financial and social aspect. The reduction of wages of public sector employees is a strictly accounting issue, which has only a minor result on the improvement of the condition of the consolidated general budget. As demonstrated in the paper, the impact of the wages' reduction, combined with the loss of income from labour taxation, was of $0.3 \%$ of the GDP. Moreover, we performed a simulation of the hypothesis of cancelling the decision to reduce public sector wages, in the conditions of maintaining the increase of the VAT level with $5 \mathrm{p}$. p. and we demonstrated that, in this case, the deficit of the general consolidated budget would have fallen within the limit agreed with the IMF. Still, cutting the public sector wages may have adverse effects of salary constraints, which may refer especially to the reduction of the moral responsibility or the decrease of professional competence, which we consider crucial for increasing the efficiency of public administration, including for the increase of the budgetary collections which would support the wages, which, in their turn support moral responsibility and professional competence.

Corrected depending on the total index of consumption prices, public expenditure recorded a real negative growth of $30.67 \%$. At first glance, this appears a positive fact, but this reduction is not corroborated with an increase of investments generating economic added value and, therefore, it (namely, the cutting of public expenditure) cannot be considered a

3 This rate, of $18.5 \%$, was valid only during the interval $12.01 .2008-01.31 .2009$. In the period 2001-2002, the rate was of $23.33 \%$, in 2003 it was $22.67 \%$, in 2004 it was $22.00 \%$, in $2005-20.00 \%$, in $2006-20.5 \%$, and in the interval $2007-11.30 .2008$ it was of $19.5 \%$. 
measure stimulating economic growth. Moreover, at the EU level, Romania has the lowest percentage of expenditure in the GDP $(41.0 \%$ compared to the EU average of $50.8 \%$, figures according to the ESA95methodology), but public incomes also have the lowest percentage of the GDP (32.4\% compared to the EU average of $44.0 \%$, figures according to the ESA95methodology). Hence, the effect of the measure to diminish public expenditure in the matter of increasing incomes is null. That is why we agree with those opinions that support the reorientation of the public budget management in view of certain measures for increasing the degree of collection of budgetary incomes (e.g. combating tax fraud and evasion, diminishing of the black economy), for reducing the social contributions shares paid by employers, rather than a financial policy focused on the drastic reduction of personnel expenditure, as was in the case in the latest period.

In countries that experience market pressures or where are in place IMF or EU programs, or a combination of the two, the impact on the public sector pay comes more from the political responses to the government stimulus measures. These responses are inherently political because they explain the economic mechanisms that make it necessary for the burden of the economic recession to be shared between all societal actors.

\section{References}

[1] Blaziene, I. (2009): Trade Union Hunger Strike Averts Public Sector Pay Cut. [on-line], Dublin, Eurofound, $12^{\text {th }}$ August, 2009; [cit. $9^{\text {th }}$ April, 2011], <http://www.eurofound.europa.eu/eiro/2009/07/articles/lt0907029i.htm>.

[2] Bretton Woods Project (2008): Back from the Dead. IMF Pumps out Loans and Conditionality. [on-line], London, Bretton Woods Project, $27^{\text {th }}$ November, 2008, [cit. $9^{\text {th }}$ April, 2011], <http://www.brettonwoodsproject.org/art-562981>.

[3] Bretton Woods Project (2009): Will IMF Loans Hurt the Poor this Time around? [on-line], London, Bretton Woods Project, $13^{\text {rd }}$ February, 2009, [cit. $9^{\text {th }}$ April, 2011], <http://www.brettonwoodsproject.org/art-563607>. 
[4] Callan, T. - Nolan, B. - Walsh, J. (2010): The Economic Crisis, Public Sector Pay, and the Income Distribution. Discussion paper series. [on-line], Bonn, The Institute for the Study of Labour, 2010. [cit. 24 ${ }^{\text {th }}$ March, 2011], 〈http://ftp.iza.org/dp4948.pdf>.

[5] Curkina, I. (2009): Wide-scale Cuts in Salaries and Social Benefits. [on-line], Dublin, Eurofound, $12^{\text {th }}$ August, 2009, [cit. $9^{\text {th }}$ April, 2011], <http://www.eurofound.europa.eu/eiro/2009/07/articles/lv0907019i.htm>.

[6] European Commission (2010): Monitoring Tax Revenues and Tax Reforms in EU Member States 2010. [on-line], Brussels, European Commission, 2010. [cit. $5^{\text {th }}$ April, 2011], http://ec.europa.eu/economy_finance/publications/european_econo my/2010/pdf/ee-2010-6_en.pdf>.

[7] Eurostat (2011): Labour cost index, nominal value - Quarterly data (Nace $R 2$ ), Seasonally adjusted and adjusted data by working days, Index, 2008=100. Luxembourg, Eurostat, 2011. Extracted $7^{\text {th }}$ April, 2011.

[8] Fiscal Council (2010): Romania, macroeconomic outlook and fiscal policy issues, [on-line], Bucharest, Fiscal Council, c2010, [cit. $24^{\text {th }}$ March 2011], <http://www.fiscalcouncil.ro/ionutppt.pdf>.

[9] Georgescu, M. A. (2011): Administrarea finantelor publice si a bugetului. Bucharest, Pro Universitaria Publishing House, 2011.

[10] Holm-Hadulla, F. (2010): Public Wages in the Euro Area: towards Securing Stability and Competitiveness. [on-line], Frankfurt am Main, European Central Bank (ECB) Occasional Paper no. 112. June 2010, [cit. 27 $7^{\text {th }}$ February, 2011], <http://www.ecb.int/pub/pdf/scpops/ecbocp112.pdf>.

[11] Kapsalis, A. (2010): Government Adopts Extraordinary Measures to Tackle Economic Crisis. [on-line], Dublin, Eurofound, $4^{\text {th }}$ May, 2010, [cit. $9^{\text {th }}$ April, 2011], <http://www.eurofound.europa.eu/eiro/2010/03/articles/gr1003029i.htm>.

[12] KPMG (2010): KPMGs Individual Income Tax and Social Security Rate Survey, 2010. [on-line], Amstelveen, KPMG, c2010, [cit. 24 ${ }^{\text {th }}$ March, 2011],

<http://www.kpmg.com/Global/en/IssuesAndInsights/ArticlesPublic ations/Documents/Individual-Income-Tax-oct-2010.pdf $>$. 
Georgescu, M.-A. - Murgescu, D. M.: Labour Taxation and Personnel Expenditure in the Romanian Public Sector.

[13] Lampousaki, L. (2010): Extraordinary Measures Used to Activate European Economic Support Mechanism. [on-line], Dublin,Eurofound, $1^{\text {st }}$ July, 2010, [cit. $9^{\text {th }}$ April, 2011], <http://www.eurofound.europa.eu/eiro/2010/05/articles/gr1005019i.htm>.

[14] Lima, M. P. C. (2010a): 300,000 Join CGTP Demonstration against Austerity Package. [on-line], Dublin, Eurofound, 10 ${ }^{\text {th }}$ August, 2010, [cit. $9^{\text {th }}$ April, 2011], <http://www.eurofound.europa.eu/eiro/2010/05/articles/pt1005019i.htm>.

[15] Lima, M. P. C. (2010b): Public Sector Trade Unions Hold General Strike against Wage Freezes and Lower Retirement Pensions. [on-line], Dublin, Eurofound, $16^{\text {th }}$ March, 2010, [cit. $9^{\text {th }}$ April, 2011], <http://www.eurofound.europa.eu/eiro/2011/02/articles/pt1102019i.htm>.

[16] MFP Romania (2006-2011): Monthly Bulletin 2006-2011. [on-line], Bucharest, Ministry of Public Finance of Romania, c2006-2011, [cit. $27^{\text {th }}$ March, 2011], <http://www.mfinante.ro/execbug.html?pagina=buletin>.

[17] Miguel, P. S. (2010): Government Endorses Plan to Cut Public Deficit. [on-line], Dublin, Eurofound, $28^{\text {th }}$ July, 2010, [cit $9^{\text {th }}$ April, 2011], <http://www.eurofound.europa.eu/eiro/2010/06/articles/es1006011i.htm>. 


\title{
Labour Taxation and Personnel Expenditure in the Romanian Public Sector
}

\author{
Maria-Andrada GEORGESCU - Dana Mihaela MURGESCU
}

\begin{abstract}
The global economic crisis, which had a strong impact on virtually all states of the world, brought additional challenges to the public sector. The governments had to choose between two alternatives: to decrease public expenditure by adopting austerity measures (option chosen by most EU Member States) or to increase public investments, in an attempt to stimulate economic growth (alternative preferred and supported by the US and Great Britain). The paper at hand aims to analyze the public expenditure policy in Romania, as a result of the economic conditions imposed by the crisis, with a focus on the relationship between the incomes collected from taxes on labour and the public expenditure with the personnel employed within public institutions. We shall analyze and compare the figures regarding public expenditure for the wages of persons working in the public sector in the years prior to the crisis and following the adoption of the austerity measures. At the same time, we shall analyze the corresponding numbers regarding the amounts collected from taxes on labour. The goal of the paper is to identify the possible connection between the reduction of personnel expenses and the decrease of the budgetary deficit, which was the intended purpose of the austerity measures in the field of public employees' salaries. Since the labour tax is computed on the basis of the salary earned, we expect both the expenses with the personnel and the amounts collected from labour tax, to decrease. However, this decrease will be in different percentages. The paper will analyze if the final balance between expenses with salaries and labour tax is positive or negative, in other words, if the austerity measures helped improve the budgetary deficit or deepened it. The final part of the research focuses on a comparative analysis between the EU Member States, with respect to the levels of taxation on labour, the percentage of labour tax in the GDP, and the public expenditure with the personnel, in an attempt to show if there are certain similarities or differences between EU and/or NISPAcee States.
\end{abstract}

Key words: Labour taxation; Public expenditure; Economic crisis.

JEL classification: J38. 